\title{
PENGARUH KOMPENSASI, DISIPLIN KERJA DAN MOTIVASI TERHADAP PRODUKTIVITAS KARYAWAN
}

\author{
Ni Kadek Ira Agustini ${ }^{1}$ \\ A.A Sagung Kartika Dewi ${ }^{2}$ \\ ${ }^{1,2}$ Fakultas Ekonomi dan Bisnis Universitas Udayana (Unud), Bali, Indonesia \\ e-mail: iraagustini3@gmail.com
}

\begin{abstract}
ABSTRAK
Keberhasilan perusahaan di tentukan oleh sumber daya manusia sehingga perusahaan perlu untuk memenuhi kebutuhan karyawan dengan begitu karyawan dapat bekerja secara produktif. Poduktivitas karyawan adalah kempuan karyawan dalam menyelesaikan tugas secara efektif dan efesiensi. Produktivitas karyawan dapat dipengaruhi oleh beberapa faktor diantaranya kompensasi, disiplin kerja dan motivasi. Tujuan penelitian ini adalah untuk mengetahui pengaruh kompensasi, disiplin kerja dan motivasi terhadap produktivitas karyawan. Penelitian ini dilakukan di Single Fin Restaurant\&Bar Bali. Jumlah responden dalam penelitian ini adalah 79 orang. Pada pengumpulan data dilakukan melalui penyebaran kuesioner dengan menggunakan metode pengukuran data skala Likert. Teknik analisis yang digunakan dalam penelitian ini adalah regresi linier berganda. Hasil analisis pada penelitian ini menunjukan bahwa masing-masing variabel kompensasi, disiplin kerja dan motivasi secara parsial berpengaruh positif dan signifikan terhadap produktivitas karyawan di Single Fin Restaurant\&Bar Bali.
\end{abstract}

Kata kunci: kompensasi, disiplin kerja, motivasi, produktivitas karyawan

\begin{abstract}
The success of the company is determined by the human resources so that the company needs to meet the needs of employees so employees can work productively. Employee's punctuality is the ability of employees to complete their tasks effectively and efficiently. Employee productivity can be affected by several factors including compensation, work discipline and motivation. The purpose of this study is to determine the effect of compensation, work discipline and motivation to employee productivity. The research was conducted at Single Fin Restaurant \& Bar Bali. The number of respondents in this study was 79 people. In the data collection is done through the spread of questionnaires using Likert scale data measurement method. The analysis technique used in this research is multiple linear regression. The results of this study showed that each variable of compensation, work discipline and motivation partially have a positive and significant effect on employee productivity at Single Fin Restaurant \& Bar Bali.

Keywords: compensation, work discipline, motivation, employee productiviy
\end{abstract}


Ni Kadek Ira Agustini. Pengaruh Kompensasi, Disiplin Kerja...

\section{PENDAHULUAN}

Keberhasilan perusahaan ditentukan oleh sumber daya manusia, karena tanpa adanya sumber daya manusia maka perusahaan tidak dapat meraih tujuan perusahaan. Sumber daya manusia yang baik dan optimal akan secara langsung berdampak kepada kesuksesan perusahaan dalam meraih tujuan perusahaan. Perusahaan yang sukses tidak sekedar memberikan tugas kepada karyawan, tetapi juga memperhatikan apa yang dibutuhkan karyawan sehingga karyawan dapat dengan nyaman untuk bekerja. Sumber daya manusia yang telah terpenuhi kebutuhanannya, secara otomatis karyawanakan memberikan lebih dari yang diharapkan oleh perusahaan sehingga produktivitas dari karyawan juga dinilai sangat baik oleh perusahaan.

Produktivitas merupakan kemampuan karyawan dalam mencapai tugas tertentu sesuai standar, kelengkapan, biaya dan kecepatan sehingga pemanfaatan sumber daya manusia yang efisien dan efektif dalam sebuah organisasi sangat penting untuk meningkatkan efektivitas dan efisiensi secara keseluruhan (Hanaysha, 2016). Produktivitas karyawan merupakan hal yang penting dalam perusahaan, jika karyawan bekerja secara produktif maka perusahaan dikatakan berhasil meraih tujuan dan jika karyawan tidak bekerja secara produktif maka perusahaan dikatakan tidak berhasil meraih tujuan perusahaan. Produktivitas karyawan juga sangat ditentukan oleh kompensasi, disiplin kerja dan motivasi. Produktivitas pada hakikatnya merupakan suatu akibat dari persyaratanpersyaratan kerja yang harus dipenuhi oleh karyawan. Seorang karyawan dapat dikatakan produktif jika dalam waktu tertentu dapat menyelesaikan pekerjaan 
yang telah ditetapkan dan ditugaskan kepadanya. Pada dasarnya seorang karyawan harus memiliki sikap yang optimis yang berakar pada keyakinan bahwa hari esok harus lebih baikdari hari ini serta harus didasarkan pada kemampuan dan keterampilan sesuai kompetensi serta harus didukung oleh disiplin kerja yang tinggi (Ruauw dkk.,2015).

Kompensasi yang rendah dapat menurunkan produktivitas karyawan dan kompensasi yang tinggi dapat meningkatkan produktivitas karyawan, pernyataan tersebut sangat jelas bahwa kompensasi merupakan aset utama agar karyawan dapat bekerja secara produktif. Pemberian kompensasi yang efektif dapat membangkitkan kemampuan tersendiri dari karyawan masing-masing sehingga perusahaan dapat melihat kemampuan para karyawannya. Kompensasi yang efektif juga dapat membuat para karyawan merasa dihargai atas kontribusi yang diberikan terhadap perusahaan. Kompensasi yang rendah dapat menurunkan produktivitas karyawan serta berdampak terhadap perilaku karyawan dan disiplin karyawan dalam bekerja. Karyawan yang tidak disiplin dalam bekerja, seperti bekerja tidak tepat waktu, tidak mematuhi peraturan perusahaan dan moral karyawan yang tidak baik.

Disiplin pada dasarnya adalah kemampauan untuk mengendalikan diri agar tidak melakukan tindakan yang tidak sesuai (Mangkunegara, 2015). Disiplin kerja merupakan kombinasi dari penghargaan, kesetiaan, kepatuhan terhadap peraturan tertulis dan tidak tertulis yang berlaku, kemampuan untuk melaksanakannya dan menerima hukumannya (Ardana dalam Arsyad,2014). Nwachukwu dalam Gabriel et al. (2015) mengamati bahwa ketidakmampuan manajemen untuk menegakkan 
disiplin dapat menjadi alasan ketidakpuasan karyawan, rendahnya moral dan akibatnya produktivitas rendah. Disiplin karyawan dapat dilihat dari tanggung jawab, sikap, tingkah laku dan tindakan karyawan selama mereka bekerja diperusahaan (Thoyib dalam Suwuh, 2015). Disiplin kerja dapat mempengaruhi produktivitas karyawan serta sangat berperan penting untuk mencapai tujuan perusahaan. Karyawan yang bekerja secara disiplin seperti datang tepat waktu, mematuhi aturan perusahaan dan mempunyai moral yang baik dalam bekerja dapat meningkatkan produktivitas karyawan. Disiplin kerja dapat tumbuh dengan adanya motivasi yang diberikan terhadap karyawan, sehingga dapat mendorong karyawan bekerja secara produktif guna mencapai tujuan perusahaan.

Motivasi karyawan bergantung pada kekuatan motifnya. Motif adalah kebutuhan, keinginan dalam individu dan dapat menentukan perilaku manusia. Oleh karena itu, motivasi adalah keadaan bantin yang memberi energi pada orang menyalurkan dan menopang tingkah laku manuisa (Maduka dan Okafor, 2014). Setiap melakukan perkerjaan karyawan membutuhkan motivasi dalam dirinya yang dapat membangkitkan antusiasme dan kegembiaraan dalam bekerja Syahrial (2016). Motivasi dapat diberikan melalui dorongan baik secara finansial maupun nonfinansial yang diberikan oleh perusahaan terhadap karyawan. Perusahaan yang kurang memberikan motivasi terhadap karyawan dapat menyebabkan kegagalan untuk mencapai tujuan perusahaan dan jika perusahaan memberikan motivasi yang lebih terhadap karyawan maka secara otomatis perusahaan berhasil mencapai tujuan perusahaan. Karyawan yang kurang memiliki motivasi tersendiri untuk bekerja dan tidak semangat dalam bekerja juga mencerminkan produktivitas 
karyawan yang menurun. Pekerja yang tidak termotivasi kurang produktif, menunjukkan perilaku yang tidak diinginkan seperti ketidakhadiran dan kecerobohan yang menyebabkan rendahnya produktivitas (Weldeyohannes, 2015). Faktor- faktor tersebut sangat jelas bahwa kompensasi, disiplin kerja dan motivasi sangat berkaitan dengan produktivitas karyawan. Perusahaan yang memberikan kompensasi yang efektif, karyawan yang disiplin dalam bekerja dan motivasi yang baik dan dapat membuat karyawan bekerja secara produktif.

Pada penelitian ini, yang dilakukan di Single Fin Restaurant \& Bar Bali mempunyai masalah dengan produktivitas karyawan. Hasil ulasan tripadvisor pada Single Fin Restaurant \& Bar Bali mendapatkan ulasan yang baik dan buruk. Ulasan yang baik lebih banyak di katakan pada tempat yang indah dan nyaman karena posisinya diatas tebing dan langsung melihat panorama pantai yang cantik. Ulasan yang buruk yaitu pada pelayanan di Single Fin Restaurant \& Bar Bali, terdapat ulasan yaitu "pemandangan yang bagus tapi makanan dan pelayanan yang payah" dalam artian rasa makanan sangat kurang enak dan harganya terlalu mahal dikarenakan rasa dan kualitas tidak sesuai, mojito yang terlalu manis dan pelayanan yang sibuk tanpa ingat untuk memberi perhatian untuk pelanggan. Kedua "pelayanan yang mengecewakan" kali ini layanan makanan sangat lamban, makanan baru keluar 1,5 jam. Ketiga "tempat yang bagus tapi layanan lambat" sama halnya makanan memakan waktu lama untuk keluar dan hal ini buruk untuk tempat yang terkenal, terdapat banyak lagi ulasan-ulasan yang membuat konsumen merasa tidak puas. Ulasan tersebut membuat konsumen merasa tidak puas dan dengan adanya makanan yang lambat datang serta kurangnya perhatian 
terhadap komsumen membuat para pelanggan berkurang untuk datang ke Single Fin Restaurant \& Bar Bali, bahkan terdapat ulasan bahwa konsumen yang telah mendapat layanan yang buruk tidak akan datang lagi ke Single Fin Restaurant \& Bar Bali, hal ini cukup membuktikan bahwa dengan pelayanan buruk dapat mengurangi konsumen, dalam artian bahwa karyawan kurang cepat dan cakap untuk melayani konsumennya sehingga produktivitas karyawan di Single Fin Restaurant \& Bar Bali dapat dikatakan rendah atau menurun.

Hasil dari wawancara yang dilakukan terhadap 5 karyawan di Single Fin Restaurant\& Bar Bali juga membuktikan bahwa terdapat masalah pada produktivitas karyawan, yaitu karyawan yang bekerja di Single Fin Restaurant \& Bar Bali tidak dapat melaksanakan tugas yang di berikan secara cepat mereka menyelesaikan perkerjaan yang ditugaskan itu dengan waktu yang cukup lama. Pada penanganan tugas yang diberikan dan dilaksanakan dalam waktu yang lama biasanya dapat mengetahui bahwa tugas tersebut dikerjakan dengan sebaik mungkin, namun pada kali ini hal tersebut terbalik bahwa nyatanya tugas yang dikerjakan tidak memiliki kualitas yang baik dan tidak sesuai harapan dari perusahaan. Tugas yang terlalu banyak dibebankan kepada karyawan membuat para karyawan kesulitan dalam menanganinya, yang sangat jelas bahwa para karyawan disini tidak dapat menyelesaikan tugas yang banyak dan berkualitas apalagi diselesaikan secara cepat yang diharapkan oleh perusahaan.

Faktor- faktor yang memicu adanya permasalahan produktivitas karyawan juga dikarenakan kompensasi yang buruk, karyawan yang tidak bekerja secara disiplin dan kurangnya motivasi dari karyawan. Pertama pada kompensasi 
terdapat masalah yaitu, karyawan tidak puas dengan kompensasi yang diterima, karena kompensasi khususnya gaji yang harusnya diterima tepat waktu dan dapat memenuhi kebutuhan karyawan malah terbalik yaitu karyawan tidak menerima gaji tepat waktu dan tidak dapat memenuhi kebutuhan karyawan. Perusahaan juga tidak memberikan tunjangan rumah sakit serta tunjangan berupa dana pensiun, sehingga membuat karyawan bekerja dengan setengah hati atau dapat dikatakan produktivitas karyawan menurun. Hasil tersebut diperoleh dari wawancara yang dilakukan kepada 5 karyawan yang bekerja di Single Fin Restaurant \& Bar Bali.

Kedua pada disiplin kerja banyak terdapat karyawan yang absen untuk tidak bekerja dalam sebulan yang dapat dilihat pada Tabel 1. sebagai berikut.

Tabel 1.

Absensi Karyawan Single Fin Restaurant \&Bar Bali, Juni-November 2017

\begin{tabular}{ccccc}
\hline Bulan & $\begin{array}{c}\text { Jumlah } \\
\text { Karyawan }\end{array}$ & $\begin{array}{c}\text { Jumlah Hari } \\
\text { Kerja }\end{array}$ & $\begin{array}{c}\text { Absen } \\
\text { Karyawan }\end{array}$ & Persentase Kehadiran \\
\hline Juni & 79 & 26 & 60 & $\frac{60}{2054} \times 100 \%=2,9 \%$ \\
Juli & 79 & 27 & 68 & $\frac{68}{2133} \times 100 \%=3,2 \%$ \\
Agustus & 79 & 27 & 75 & $\frac{75}{2133} \times 100 \%=3,5 \%$ \\
September & 79 & 26 & 75 & $\frac{75}{2054} \times 100 \%=3,7 \%$ \\
Oktober & 79 & 27 & 77 & $\frac{77}{2133} \times 100 \%=3,6 \%$ \\
November & 79 & 26 & 71 & $\frac{71}{2054} \times 100 \%=3,5 \%$ \\
\hline
\end{tabular}

Sumber: Single Fin Restaurant \& Bar Bali, Juni-November 2017

Menurut Flippo dalam Sutrisno (2013) menyatakan bahwa batas maksimal yang lazim berlaku pada absensi yaitu sebesar 3\%, yang berarti angka 3,2\% 
Ni Kadek Ira Agustini. Pengaruh Kompensasi, Disiplin Kerja...

sampai 3,7\% merupakan ciri dari karyawan yang tidak disiplin dan angka dibawah 3\% masih dikatakan karyawan yang disiplin. Pada Tabel 1diatas dapat dilihat bahwa absen 3,2\% sampai 3,7\% yang dominan, hal tersebut dapat kita ketahui terdapat ciri-ciri karyawan tidak disiplin. Karyawan yang tidak disiplin dapat kita ketahui bahwa karyawan tidak mempunyai rasa tanggu jawab dan taat dengan aturan yang berlaku. Ketidak disiplinan kerja karyawan dapat menyebabkan kurangnya efisiensi kerja dan efektivitas pekerjaan serta perusahaan tidak dapat meraih tujuannya, sehingga dapat dikatakan produktivitas karyawan menurun. Karyawan yang memiliki disiplin kerja yang tinggi akan berdampak kepada karyawan itu sendiri dalam merah prestasi dan berdampak kepada perusahaan dalam pencapaian target yang optimal. Wawancara yang dilakukan kepada manajer mengatakan bahwa terdapat karyawan yang datang terlambat dan karyawan keluar dari perusahaan tanpa meminta izin terlebih dahulu dan pakaian seragam yang digunakan tidak sesuai dengan ketentuan. Ketiga yaitu motivasi yaitu, karyawan kurang termotivasi untuk bekerja, seperti dalam menghadapi tantangan yang tidak bisa dipertahankan maupun diselesaikan dan karyawan langsung menyerah dan putus asa akantantangan atau tugas tersebut. Karyawan juga tidak memiliki inisiatif dan kegigihan dalam bekerja, hal tersebut di peroleh hasil wawancara dari 4 karyawan yang bekerja di Single Fin Restaurant \&Bar Bali.

Single Fin Restaurant \& Bar Bali merupakan perusahaan yang bergerak di bidang jasa makanan, minuman, dan surf shop. Single Fin Restaurant \& Bar Bali yang berlokasi di Jalan Labuan Sait, Pantai Suluban, Uluwatu, Kuta Selatan, 
Kabupaten Badung, Bali dan mulai beroperasi pada bulan Maret 2011. Single Fin Restaurant \& Bar Bali selain menyediakan makanan, minuman dan surf shop juga memiliki pemandangan pantai yang indah yang dapat dinikmati oleh para tamu dan juga pada sore hari dapat melihat pemandangan sunset.

Beberapa penelitian terdahulu menyatakan kompensasi, disiplin kerja dan motivasi berpengaruh positif terhadap produktivitas karyawan. Penelitian yang dilakukan oleh Yamoah (2013) yang berjudul RelationshipBetwen Compensation and Employee Productivity menyatakan bahwa kompensasi berpengaruh positif terhadap produktivitas karyawan. Penelitian yang dilakukan oleh Ananta \& Adnyani (2016) yang berjudul Pengaruh disiplin Kerja dan Budaya Organisasi terhadap Produktivitas Kerja Karyawan pada Villa Mahapala Sanur-Denpasar menyatakan bahwa disiplin kerja berpengaruh positif terhadap produktivitas karyawan. Penelitian yang dilakukan oleh Khan \& Gautam (2014) yang berjudul A Study of Impact of Motivation on Productivity of Employee menyatakan bahwa motivasi berpengaruh positif terhadap produktivitas karyawan.

Tujuan peneletian ini yakni untuk menganalisis pengaruh kompensasi terhadap produktivitas keryawan di Single Fin Restaurant \& Bar Bali. Untuk menganalisis pengaruh disiplin kerja terhadap produktivitas keryawan di Single Fin Restaurant \& Bar Baliserta untuk menganalisis pengaruh motivasi terhadap produktivitas keryawan di Single Fin Restaurant \& Bar Bali. Penelitian ini dharapkan agar mahasiswa mampu menerapkan ilmu yang telah dipelajari ini melalui penelitian ini, sehingga dapat mengetahui pengaruh kompensasi, disiplin kerja dan motivasi terhadap produktivitas karyawan yang dimana dapat sangat 
berperan untuk keefektifan kerja dan kesuksesan perusahaan nantinya. Penelitian ini diharapkan dapat membatu sebuah perusahaan yang mempunyai masalah sama persis dengan bidang ini untuk membantu memecahkan masalah dengan memberikan masukan tentang pentingnya kompensasi, disiplin kerja dan motivasi terhadap produktivitas karyawan yang dimana juga untuk mencapai tujuan perusahaan tersebut.

Kerangka konseptual yang diajukan sebagai dasar penentu hipotesis ditunjukan pada Gambar 1 sebagai berikut.

Gambar 1. Kerangka Konseptual Penelitian

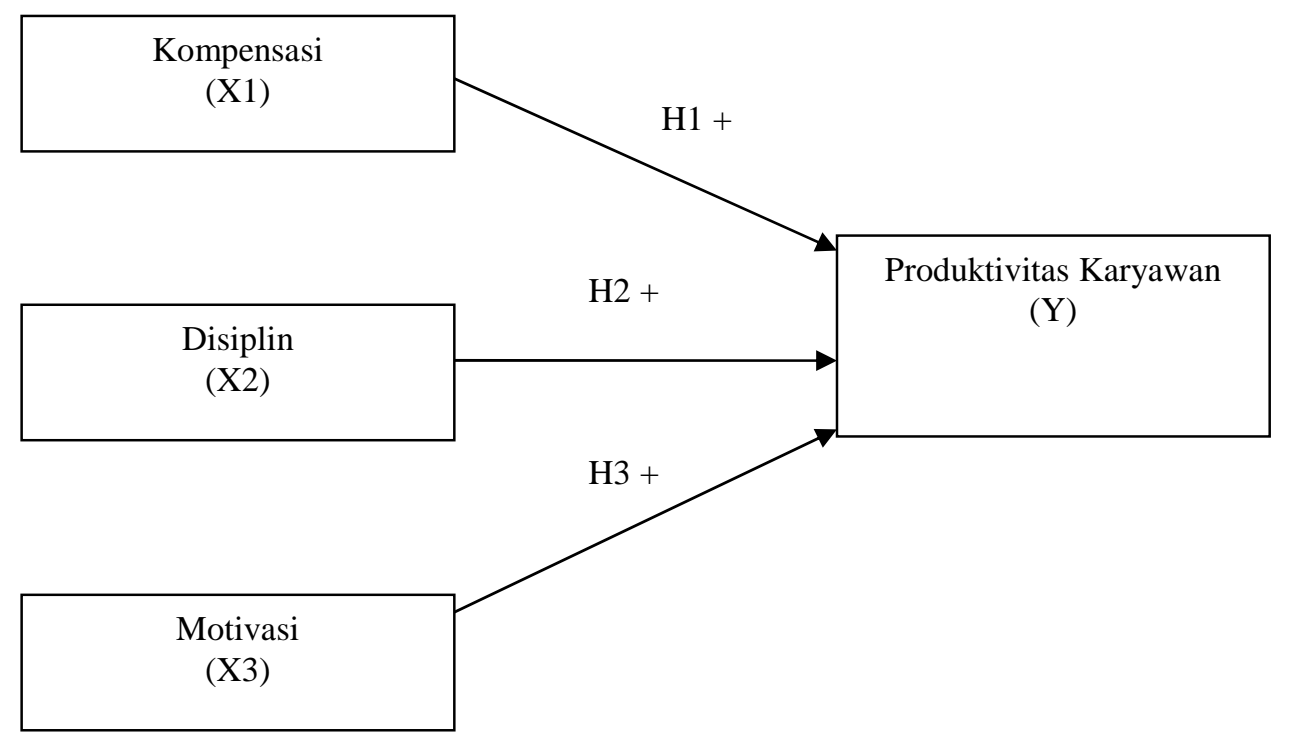

Kadarsiman (2012) menyatakan bahwa kompensasi adalah imbal balik dari pekerjaan. Abdussamad (2014) kompensasi buruk dapat menurunkan produktivitas kerja karyawan. Purwanto dan Wulandari (2016) menyatakan jika karyawan memperoleh peningkatan gaji, insentif yang bagus, bonus dan mendapat gaji tepat waktu akan meningkatkan produktivitas karyawan. Pada penelitian yang dilakukan oleh Abdussamad (2014) yang berjudul Pengaruh Kompensasi terhadap Produktivitas Kerja Karyawan pada PT Asuransi Jiwasraya Gorontalo, Wardoyo 
(2016) yang berjudul The Influence of the Discipline and Compensation against Work Productivity (Study on the Security Services Company, PT Garuda Milky Artha Surabaya),Yamoah (2013) yang berjudul Relationship Between Compensation and Employee Productivity, Saharuddin \& Sulaiman (2016) yang berjudul The Effect of Promotion and Compensation Toward Working Productivity Trough Job Satisfaction and Working Motivation of Employees in The Department of Water and Mineral Resources Energy North Aceh District dan penelitian yang dilakukan oleh Yuliandari dkk. (2016) yang berjudul Pengaruh Kompensasi dan Lingkungan Kerja terhadap Produktivitas Karyawan bagian Loster pada UD Yuri Desa Pangkung Buluh Kecamatan Melaya Kabupaten Jembrana diperoleh hasil kompensasi berpengaruh positif terhadap produktivitas karyawan. Jadi hipotesis pertama yang diajukan dalam penelitian ini adalah:

$\mathrm{H}_{1}$ : Kompensasi berpengaruh positif dan signifikan terhadap Produktivitas Karyawan

Siagian dalam Elqadriet al. (2015) menyatakan bahwa mendisiplinkan bawahan atas pelanggaran peraturan. Labudo (2013) menyatakan bahwa peningkatan produktivitas dicapai jika karyawan mempunyai disiplin kerja dalam melaksanakan tugas dan kewajibannya. Nwachukwu dalam Gabriel Cet al. (2015) mengamati bahwa ketidakmampuan manajemen untuk menegakkan disiplin dapat mengakibatkan produktivitas rendah. Pada penelitian yang dilakukan oleh Labudo (2013) yang berjudul Disiplin Kerja dan Kompensasi Pengaruhnya terhadap Produktivitas Karyawan, Wardoyo (2016) yang berjudul The Influence of the Discipline and Compensation against Work Productivity (Study on the Security Services Company, PT Garuda Milky Artha Surabaya), Ruauw dkk. (2015) yang 
Ni Kadek Ira Agustini. Pengaruh Kompensasi, Disiplin Kerja...

berjudul Pengaruh Disiplin Kerja terhadap Produktivitas Pegawai (Suatu Studi di Kantor Kelurahan Tingkulu Kecamatan Wanea Kota Manado), Christian dan Farida (2016) yang berjudul Pengaruh Disiplin Kerja terhadap Produktivitas Kerja Karyawan bagian Produksi Pabrik Kelapa Sawit (PKS) PT. Perkebunan Nusantara V Sei Rokan Kec. Pagaran Tapah Darussalam Kab. Rokan Hulu serta penelitian yang dilakukan oleh Ananta dan Adnyani (2016) yang berjudul Pengaruh disiplin Kerja dan Budaya Organisasi terhadap Produktivitas Kerja Karyawan pada Villa Mahapala Sanur-Denpasardiperoleh hasil disiplin kerja berpengaruh positif terhadap produktivitas karyawan. Jadi hipotesis kedua yang diajukan dalam penelitian ini adalah:

$\mathrm{H}_{2}$ : Disiplin berpengaruh positif dan signifikan terhadap Produktivitas Karyawan Hamali (2013) menyatakan bahwa motivasi adalah motif yang berarti suatu alasan untuk melakukan sesuatu dan kekutan yang dapat membangkitkan, mengarahkan dan menopang perilaku. Karyawan yang kurang memiliki motivasi tersendiri untuk bekerja dan tidak semangat dalam bekerja juga mencerminkan produktivitas karyawan yang menurun. Sutanto dan Patty (2014) menyatakan bahwa, jika motivasi dari para karyawan bisa dibangun, maka para karaywan dapat memiliki hasil kerja yang produktif. Pada penelitian yang dilakukan oleh Purwanto dan Wulandari (2016) yang berjudul Pengaruh Motivasi, Kompensasi dan Lingkungan Kerja terhadap Produktivitas Kerja Karyawan, Elqadriet al.(2015) yang berjudul The Influence of Motivation and Discipline Work against Employee Work Productivity Tona'an, Jayarathna (2014) yang berjudul An Empirical Investigation of the Impact of Employee Motivation and Productivity of 
Executive Employees with Special Reference to the Apparel Industry in Sri Lanka serta penelitian yang dilakukan oleh Khan dan Gautam (2014) yang berjudul $A$ Study of Impact of Motivation on Productivity of Employee diperoleh hasil motivasi berpengaruh positif terhadap produktivitas karyawan. Jadi hipotesis ketiga yang diajukan dalam penelitian ini adalah:

$\mathrm{H}_{3}$ : Motivasi berpengaruh positif dan signifikan terhadap Produktivitas Karyawan METODE PENELITIAN

Penelitian ini dilakukan di Single Fin Restaurant \& Bar Bali yang berlokasi di Jalan Labuan Sait, Pantai Suluban, Uluwatu, Kuta Selatan, Kabupaten Badung, Bali untuk membantu memecahkan masalah mengenai produktivitas karyawan, agar dapat lebih meningkatkan produktivitas karyawan di Single Fin Restaurant \& Bar Bali.

Hanaysha(2016) menyatakan bahwa produktivitas karyawan merupakan persepsi karyawan terhadap kemampuan karyawan dalam mencapai tugas.Indikator ini mengadopsi (Simamora dalam Saputra, 2014)sebagai berikut: 1). Kuantitas kerja $\left(\mathrm{Y}_{1}\right)$, indikator ini dapat diukur melalui pekerjaan dilakukan dalam jumlah besar setiap hari dan target- target yang di berikan dalam tim terpenuhi;2). Kualitas kerja $\left(\mathrm{Y}_{2}\right)$, indikator ini dapat diukur melalui penyelesaian tugas dengan standar yang baik dan hasil pekerjaan selalu berkualitas; 3). Ketepatan waktu $\left(\mathrm{Y}_{3}\right)$, indikator ini dapat diukur melalui penyelesaian tugas dengan cepat.

Ardana (2012) menyatakan bahwa kompensasi merupakan persepsi karyawan terhadap retribusi atas kontibusi karyawan untuk perusahaan. Indikator 
Ni Kadek Ira Agustini. Pengaruh Kompensasi, Disiplin Kerja...

ini mengadopsi (Atmajawati dalam Irbayuni, 2012) sebagai berikut: 1). Gaji $\left(\mathrm{X}_{1.1}\right)$, indikator ini dapat diukur melalui gaji diberikan tepat waktu, mendapat kenaikan gaji setiap tahun, gaji dapat memenuhi kebutuhan hidup, gaji sesuai dengan pekerjaan dan merasa puas dengan gaji yang diterima;2). Insentif $\left(\mathrm{X}_{1.2}\right)$, indikator ini dapat diukur melalui mendapat bonus berupa uang lembur bila bekerja diluar jam kerja; 3). Tunjangan $\left(\mathrm{X}_{1.3}\right)$, indikator ini dapat diukur melalui mendapat fasilitas kesehatan untuk keluarga, tunjangan hari raya (THR) setiap tahun, tunjangan berupa dana pensiun dan puas dengan tunjangan yang diberikan.

Siagian dalam Elqadri et al.(2015) menyatakan disiplin kerja adalah persepsi karyawan terhadap bentuk pelatihan dalam memperbaikisikap dan perilaku. Indikator ini mengadopsi Suwondo dan Sutanto (2015) sebagai berikut 1). Ketepatan waktu kerja $\left(\mathrm{X}_{2.1}\right)$, indikator ini dapat diukur melalui datang lebih awal di tempat kerja, pulang kerja sesuai dengan jam yang telah ditentukan, makan siang saat jam istirahat dan kembali ketempat kerja sebelum jam istirahat berakhir; 2). Kerapian berpakaian $\left(\mathrm{X}_{2.2}\right)$, indikator ini dapat diukur melalui kerapian seragam saat jam kerja selalu diperhatikan; 3). Kepatuhan pada aturan perusahaan $\left(\mathrm{X}_{2.3}\right)$, indikator ini dapat diukur melalui hadir setiap hari ditempat kerja, memberikan surat keterangan dokter saat tidak masuk kerja karena sakit dan memakai seragam sesuai dengan hari yang titetapkan; 4). Tanggung jawab $\left(\mathrm{X}_{2.4}\right)$, indikator ini dapat diukur melalui tugas dikerjakan dengan tanggung jawab dan bertanggung jawab atas kesalahan yang telah dilakukan.

Hamali (2013) menyatakan bahwa motivasi adalah persepsi karyawan terhadap suatu alasan dalam melakukan sesuatu. Indikator ini mengadopsi Sutanto 
dan Patty (2014) sebagai berikut: 1). Arah perilaku $\left(\mathrm{X}_{3.1}\right)$, indikator ini dapat diukur melalui relasi yang baik dengan rekan kerja; 2$)$. Tingkat usaha $\left(\mathrm{X}_{3.2}\right)$, indikator ini dapat diukur melalui bekerja dengan keterampilan tertentu yang dimiliki dan berusaha mengerjakan pekerjaan sebaik mungkin; 3). Tingkat kegigihan $\left(\mathrm{X}_{3.3}\right)$, indikator ini dapat diukur melalui pantang menyerah atau tidak mudah putus asa, gigihan dalam bekerja walaupun keadaan lingkungan kurang mendukung, berinisiatif untuk memecahakan masalah dan bertahan meski menghadapi tantangan pekerjaan (endurance).

Populasi pada penelitian ini adalah seluruh karyawan yang bekerja di Single Fin Restaurant \& Bar Bali. Jadi keseluruhan karyawan yang bekerja di Single Fin Restaurant \&Bar Bali sebesar 79orang.Teknik pengambilan sampel dalam penelitian ini adalah menggunakan teknik sampel jenuh, yang dimana keseluruhan karyawan di Single Fin Restaurant \& Bar Bali dijadikan sampel. Jadi, sampel sebesar 79 orang.

Metode pengumpulan data yang digunakan dalam penelitian ini ada dua, yaitu wawancara dan kuesioner. Wawancara merupakan metode pengumpulan data dengan melakukan tanyajawab secara langsung dengan karyawan di Single Fin Restaurant \& Bar Bali mengenai hal-hal yang berhubungan dengan penelitian.Kuesioner merupakan metode pengumpulan data yang dilakukan dengan cara memberi seperangkat pertanyaan tertulis secara terstruktur pada responden penelitian yang diambil dari beberapa pertanyaan pada penelitian sebelumnya. Memudahkan pemahaman responden, maka diubah menjadi 
statemen yang menggunakan 5 poin skala Likert yaitu sangat tidak setuju, tidak setuju, netral, setuju dan sangat setuju.

Jenis data yang digunakan dalam penelitian ini adalah: 1). Data Kualitatif, yaitu data yang disajikan dalam bentuk kata verbal dan bukan dalam bentuk angka. Data kualitatif yaitu gambaran umum objek penelitian, meliputi sejarah singkat berdirinya, letak geografis obyek, visi dan misi, struktur organisasi, keadaan hotel, keadaan karyawan, keadaan sarana prasarana, standar penilaian serta pelaksanaan kerja dan efektivitas dalam kerja; 2). Data Kuantitatif, yaitu jenis data yang dapat diukur atau dihitung secara langsung yang berupa informasi atau penjelasan yang dinyatakan dengan bilangan atau bentuk angka. Data kuantitatif memerlukan jumlah pegawai tetap dan pegawai kontrak, jumlah sarana dan prasarana, dan hasil angket.

Penelitian ini menggunakan uji instrumen terlebih dahulu kemudian dilakukan uji asumsi klasik. Metode regresi linier beranda digunakan dalam penelitian ini untuk mengetahui pengaruh Kompensasi $\left(\mathrm{X}_{1}\right)$, Disiplin Kerja $\left(\mathrm{X}_{2}\right)$, Motivasi $\left(\mathrm{X}_{3}\right)$ dan Produktivitas Karyawan $(\mathrm{Y})$. Pengaruh variabel independen terhadap variabel dependen diuji dengan tingkat kepercayaan 95\% atau $\alpha=5 \%$. Model regresi yang digunakan adalah sebagai berikut:

$$
\mathrm{Y}=\alpha+\beta 1 \mathrm{X} 1+\beta 2 \mathrm{X} 2+\beta 3 \mathrm{X} 3 \varepsilon
$$

Keterangan:

$\mathrm{Y}=$ Produktivitas Karyawan

$\mathrm{X} 1$ = Kompensasi

$\mathrm{X} 2=$ Disiplin Kerja

X3 =Motivasi

$\alpha=$ Konstanta

$\beta 1=$ Koefisien regresi Kompensasi

$\beta 2=$ Koefisien regresi Disiplin Kerja 
$\beta 3=$ Koefisien regresi Motivasi

$\varepsilon=$ Standar eror

\section{PEMBAHASAN}

Single Fin Restaurant \& Bar Bali merupakan perusahaan yang bergerak di bidang jasa makanan, minuman, dan surf shop. Single Fin Restaurant \& Bar Bali yang berlokasi di Jalan Labuan Sait, Pantai Suluban, Uluwatu, Kuta Selatan, Kabupaten Badung, Bali dan mulai beroperasi pada bulan Maret 2011. Single Fin Restaurant \& Bar Bali selain menyediakan makanan, minuman dan surf shop juga memiliki pemandangan pantai yang indah yang dapat dinikmati oleh para tamu dan juga pada sore hari dapat melihat pemandangan sunset.

Single Fin Restaurant \& Bar Bali kaya dengan pesona pantai yang sangat cantik dan membuat tempat tersebut nyaman untuk dikunjungi. Makanan seperti pizza dan makanan internasional lainnya serta berbagai minuman koktail dapat kita jumpai dengan harga sedang yang tidak terlalu mahal dan tidak terlalu murah.

Struktur organisasi yang digunakan di Single Fin Restaurant \& Bar Bali adalah struktur garis. Struktur organisasi garis merupakan bentuk organisasi yang paling sederhana karena kekuasaan berada pada satu orang pimpinan, dimana pelimpahan kekuasaan (tugas dan wewenang) dilakukan secara vertikal dari atasan kepada bawahan, begitu pula bawahan juga bertanggung jawab secara vertikal kepada atasan.

Responden laki-laki sebesar $72,15 \%$ dan responden perempuan sebesar 27,85\%. Hal ini menunjukan bahwa responden laki-laki lebih banyak dibutuhkan dibandingkan dengan responden perempuan, ini karena karyawan laki-laki lebih 
Ni Kadek Ira Agustini. Pengaruh Kompensasi, Disiplin Kerja...

banyak dibutuhkan pada divisi Manager, Bar, Food and Beverages Kitchen, Food and Beverages Service dan Security. Kelompok usia yang paling dominan adalah pada usia 20 - 24 tahun dengan presentase 49,37\% hal ini menunjukkan bahwa sebagian dari responden merupakan usia produktif dalam bekerja dan mampu memberikan lebih banyak ide-ide inovatif.

Karakteristik responden berdasarkan tingkat pendidikan yang paling dominan adalah responden dengan tingkat pendidikan terakhir D1/D2 yaitu $41,77 \%$, sedangkan responden yang paling rendah jumlahnya adalah responden dengan pendidikan terakhir S1 sebanyak 17,72\%. Hal ini menunjukan bahwa responden dengan pendidikan D1/D2 dengan presentase paling banyak karena berasal dari pendidikan perhotelan yang memang benar-benar dibutuhkan di Single Fin Restaurant \& Bar Bali.

Pertama dilakukan uji instrumen yakni uji validitas bertujuan untuk menilai instrumen yang digunakan telah tepat untuk mengukur indikator dalam penelitian. Hasil pengukuran validitas masing - masing instrumen pada variabel disajikan dalam Tabel 2 sebagai berikut.

Tabel 2.

Hasil Uji Instrumen Validitas

\begin{tabular}{ccccc}
\hline No & Variabel & $\begin{array}{c}\text { Item } \\
\text { Pernyataan }\end{array}$ & $\begin{array}{c}\text { Koefisien } \\
\text { Korelasi }\end{array}$ & Keterangan \\
\hline 1 & Produktivitas Karyawan (Y) & Y.1 & 0,567 & Valid \\
& & Y.2 & 0,730 & Valid
\end{tabular}


E-Jurnal Manajemen, Vol. 8, No. 1, 2019: 7191 - 7218

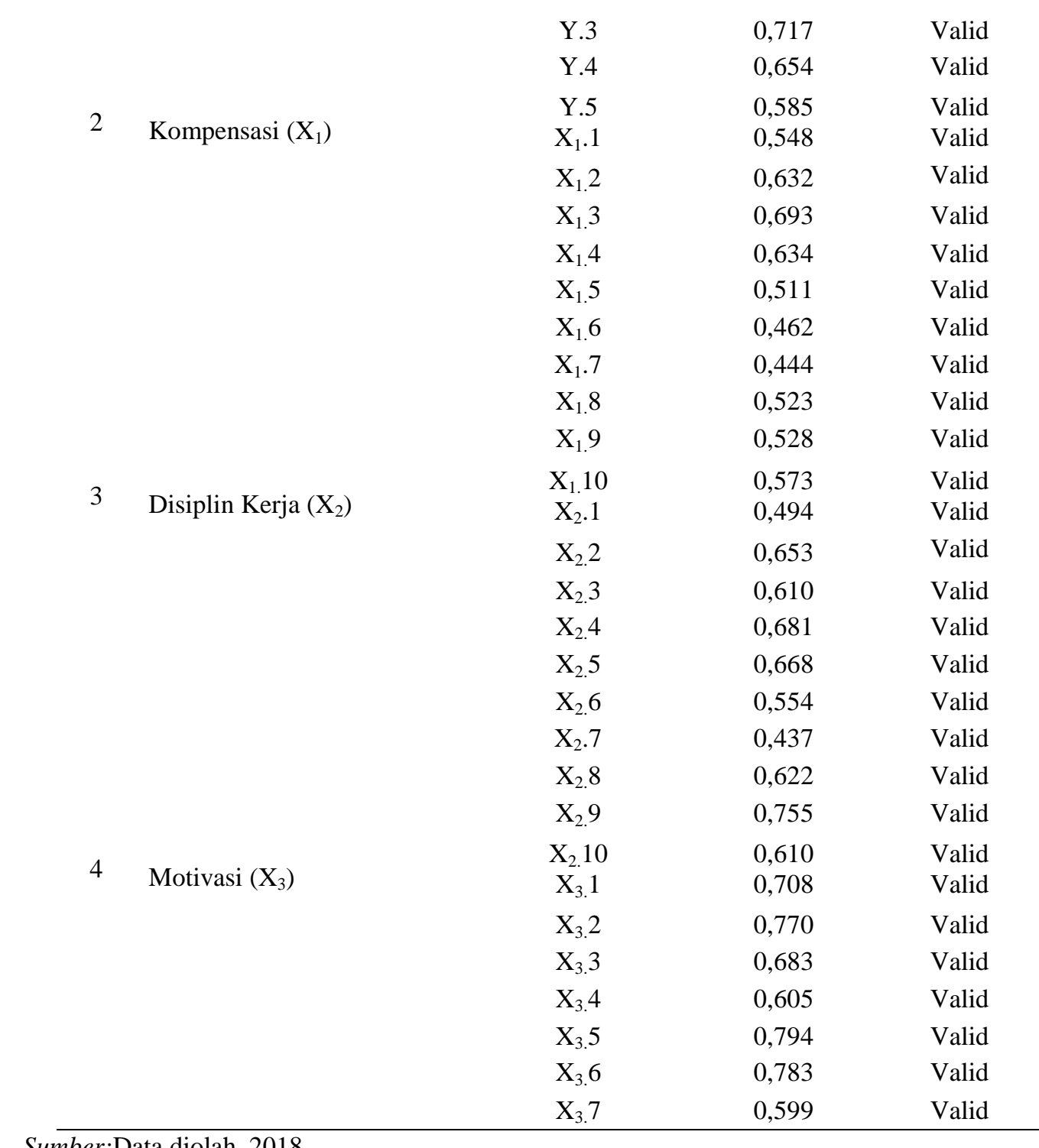

Sumber:Data diolah, 2018

Hasil uji validitas instrumen penelitian disajikan pada Tabel 2 yang menunjukkan bahwa seluruh indikator dalam variabelkualitas layanan, citra perusahaan, dan loyalitas nasabah memiliki nilai Pearson Correlation yang lebih besar dari angka 0,30 sehingga seluruh indikator tersebut dikatakan telah memenuhi syarat validitas data. 
Uji Reliabilitas bertujuan untuk mengukur konsistensi alat ukur yang digunakan. Hasil pengukuran reliabilitas masing-masing variabel disajikan dalam Tabel 3 sebagai berikut.

Tabel 3.

Hasil Uji Reabilitas

\begin{tabular}{clcc}
\hline No & Variabel & $\begin{array}{c}\text { Nilai Cronbach's } \\
\text { Alpha }\end{array}$ & Keterangan \\
\hline 1 & Produktivitas & 0,638 & Reliabel \\
2 & Kompensasi & 0,744 & Reliabel \\
3 & Disiplin Kerja & 0,808 & Reliabel \\
4 & Motivasi & 0,827 & Reliabel \\
\hline Sumber: & Data diolah, 2018 & &
\end{tabular}

Sumber: Data diolah, 2018

Hasil uji reliabilitas instrumen pada penelitian ini disajikan pada Tabel 3yang menunjukkan bahwa ketiga instrumen penelitian yaitu variabelkualitas layanan, citra perusahaan, dan loyalitas nasabah memiliki koefisien cronbach's alpha yang lebih besar dari angka 0,60 sehingga pernyataan pada kuesioner dapat dikatakan reliabel dan indikator yang digunakan merupakan indikator yang konsisten.

Selanjutnya dilakukan uji asumsi klasik. Jika nilai Asymp. Sig. (2-tailed) lebih besar taraf signifikansi yang ditetapkan yaitu 5 persen $(0,05)$, maka data telah berdistribusi normal Ghozali (2011). Berdasarkan hasil analisis, diperoleh hasil sebesar 0,810>0,05 yang artinya data berdistribusi normal. Pada hasil uji heteroskedastitas menunjukan bahwa signifikansinya lebih dari $\alpha=0,05$. Berdasarkan hal tersebut, maka dapat disimpulkan bahwa dalam model tersebut tidak terdapat heteroskedastitas, sehingga layak digunakan unuk memprediksi variabel dependen. Berdasarkan hasil analisis, dapat dilihat bahwa koefisien Tolerance semua variabel lebih besar dari 0,10 dan nilai VIF yang lebih kecil dari 
10. Hasil ini mengindikasikan bahwa tidak terdapat gejala multikolinear dari model regresi yang dibuat.

Metode regresi linier beranda digunakan dalam penelitian ini untuk mengetahui pengaruh Kompensasi $\left(\mathrm{X}_{1}\right)$, Disiplin Kerja $\left(\mathrm{X}_{2}\right)$, Motivasi $\left(\mathrm{X}_{3}\right)$ dan Produktivitas Karyawan (Y). Metode ini diuji menggunakan sistem komputer berupa spss.21 For Windows, maka diperoleh hasil seperti tabel dibawah ini:

Tabel 4.

Analisis Regresi Linier Berganda

\begin{tabular}{|c|c|c|c|c|c|c|}
\hline & \multirow[b]{2}{*}{ Model } & \multicolumn{2}{|c|}{ Unstandardized Coefficients } & \multirow{2}{*}{$\begin{array}{l}\text { Standardized } \\
\text { Coefficients } \\
\text { Beta }\end{array}$} & \multirow[b]{2}{*}{$\mathbf{t}$} & \multirow[b]{2}{*}{ Sig. } \\
\hline & & B & Std. Error & & & \\
\hline \multirow{4}{*}{1} & (Constant) & 5.321 & 1.858 & & 2.864 & .005 \\
\hline & $\mathrm{X} 1$ & .152 & .051 & .292 & 2.991 & .004 \\
\hline & $\mathrm{X} 2$ & .243 & .062 & .307 & 2.422 & .009 \\
\hline & $\mathrm{X} 3$ & .261 & .074 & .425 & 3.525 & .001 \\
\hline
\end{tabular}

Berdasarkan Tabel 4 dapat diketahui persamaan regresi yang diperoleh adalah:

$Y=5,321+0,152 X_{1}+0,243 X_{2}+0,261 X_{3}+e$

Uji $\mathrm{F}$ dilakukan dengan melihat nilai signifikansi pada tabel anova. Berdasarkan hasil uji, nilai signifikansi $\mathrm{F}$ adalah sebesar 0,000 yang lebih kecil dari $0,05(\mathrm{~F}<\alpha)$ maka model ini dikatakan layak atau variabel bebas mampu menjelaskan variabel terikat. Besarnya nilai adjusted $\mathrm{R}$ square adalah sebesar 0,357 yang artinya sebesar 35,7 persen variasi produktivitas karyawan dipengaruhi oleh kompensasi, disiplin kerja, dan motivasi, sedangkan sisanya sebesar 64,3 persen dipengaruhi oleh faktor-faktor lain yang tidak dimasukkan ke dalam model penelitian. 
Ni Kadek Ira Agustini. Pengaruh Kompensasi, Disiplin Kerja...

Berdasarkan hasil analisis data diperoleh bahwa kompensasi berpengaruh positif dan signifikan terhadap produktivitas karyawan dengan hasil (Sig. t, 0,004 $\leq 0,05)$ serta koefisien beta sebesar 0,152 yang menunjukan bahwa kompensasi secara positif berpengaruh signifikan terhadap produktivitas karyawan di Single Fin Restaurant \& Bar Bali. Hal tersebut berarti bahwa semakin bagus kompensasi yang diberi maka semakin baik produktivitas karyawan di Single Fin Restaurant \& Bar Bali. Pernyataan ini mendukung temuan dari Abdussamad (2014), Wardoyo (2016), Yamoah (2013), Saharuddin dan Sulaiman (2016), dan Yuliandari dkk. (2016) yang menyatakan bahwa kompensasi berpengaruh positif terhadap produktivitas karyawan. Berdasarkan hasil yang diperoleh maka hipotesis pengaruh kompensasi terhadap produktivitas karyawan dapat diterima.

Berdasarkan hasil analisis data diperoleh bahwa disiplin kerja berpengaruh positif dan signifikan terhadap produktivitas karyawan dengan hasil (Sig. t, 0,009 $\leq 0,05)$ serta koefisien beta sebesar 0,243 yang menunjukan bahwa disiplin kerja secara positif berpengaruh signifikan terhadap produktivitas karyawan di Single Fin Restaurant \& Bar Bali. Pernyataan ini mendukung temuan dari Labudo (2013), Wardoyo (2016), Ruauw dkk.(2015), Christian dan Farida (2016) dan Ananta dan Adnyani (2016) yang menyatakan bahwa disiplin kerja berpengaruh positif terhadap produktivitas karyawan. Berdasarkan hasil yang diperoleh maka hipotesis pengaruh disiplin kerja terhadap produktivitas karyawan dapat diterima.

Berdasarkan hasil analisis data diperoleh hasil bahwa motivasi berpengaruh positif dan signifikan terhadap produktivitas karyawan dengan hasil (Sig. t, 0,001 $\leq 0,05)$ serta koefisien beta sebesar 0,261 yang menunjukan bahwa motivasi 
secara positif berpengaruh signifikan terhadap produktivitas karyawan di Single Fin Restaurant \& Bar Bali. Pernyataan ini mendukung temuan dari Purwanto dan Wulandari (2016), Elqadriet al.(2015), Jayarathna (2014), dan Khan dan Gautam (2014) yang menyatakan bahwa motivasi berpengaruh positif terhadap produktivitas karyawan. Berdasarkan hasil yang diperoleh maka hipotesis pengaruh motivasi terhadap karyawan dapat diterima.

Implikasi hasil penelitian yakni karyawan Single Fin Restaurant \& Bar Bali mempunyai motivasi yang tinggi dalam bekerja, walaupun dalam keadaan lingkungan yang ramai karyawan tetap semangat dalam melaksanakan tugasnya masing-masing serta bekerja dengan hasil yang baik dan cepat sehingga dapat membuat konsumen puas. Lingkungan yang ramai akan konsemen lebih membuat karyawan di Single Fin Restaurant \& Bar Bali semangat untuk bekerja seperti halnya karyawan tekun dalam bekerja karena ada rasa semangat saat melihat konsumen datang begitu banyak. Hal ini dikarenakan motivasi mempunyai nilai beta tertinggi yaitu 0,261 .

Displin kerja di Single Fin Restaurant \& Bar Bali mempunyai tingkat kedisiplinan yang baik, dikarenakan konsumen yang begitu banyak membuat karyawan harus bekerja dengan tepat waktu, seperti halnya datang ditempat kerja sesuai jam kerja dan istirahat sesuai jam istirahat. Tuntutan dari konsumen yang banyak membuat karyawan tidak boleh bekerja semena-mena. Karyawan harus selalu fokus dan serius dalam melayani konsumen dengan begitu konsumen merasa puas. Hal ini dikarenakan disiplin kerja mempunyai nilai beta sebesar 0,243 . 
Ni Kadek Ira Agustini. Pengaruh Kompensasi, Disiplin Kerja...

Kompensasi yang diterima karyawan cukup bagus namun tidak dapat memenuhi kebutuhan hidup karyawan disaat mempunyai keadaan yang tak terduga. Satu hal yang kurang yaitu memberikan fasilitas kesehataan, karena dengan gaji saja tidak mencukupi, hal ini terkadang membuat karyawan sebagaian bekerja tanpa rasa semangat yang berdampak pada hasil kerja yang tidak bagus. Hal ini dikarenakan kompensasi mempunyai nilai beta terendah yaitu sebesar 0,152 .

\section{SIMPULAN DAN SARAN}

Berdasarkan hasil pembahasan penelitian yang telah dilakukan, maka dapat disimpulkan bahwa: 1). Kompensasi berpengaruh positif dan signifikan terhadap produktivitas karyawan di Single Fin Restaurant \& Bar Bali; 2). Disiplin kerja berpengaruh positif dan signifikan terhadap produktivitas karyawan di Single Fin Restaurant \& Bar Bali 3). Motivasi berpengaruh positif dan signifikan terhadap produktivitas karyawan di Single Fin Restaurant \& Bar Bali

Saran yang dapat diberikan yakni manajer Single Fin Restaurant \& Bar Bali semestinya memberikan motivasi kepada karyawannya dan pelatihan kembali disetiap tugas yang tidak dikuasai, serta berikan gaji tambahan jika ada peningkatan kerja serta di awasi setiap pekerjaan yang dilakukan sehingga karyawan dapat melaksanakan tugas dengan baik dan berkualitas. Manajer Single Fin Restaurant \& Bar Bali sebaiknya memberikan dana pensiun kepada karyawan yang nantinya akan pensiun kerja, sehingga dapat meningkatkan produktivitas karyawan. 
Manajer Single Fin Restaurant \& Bar Bali memberi peringatan dan ketegasan dalam hal ketaatan memakai seragam kerja sehingga tidak terulang lagi.Manajer Single Fin Restaurant \&Bar Bali memberikan pelatihan terus menerus bagi karyawan yang tidak dapat beradaptasi dengan tantangan yang ada, sehingga tercapainya produktivitas karyawan yang bagus dan dapat bertahan dengan tantangan yang dihadapi.

\section{DAFTAR RUJUKAN}

Abdussamad, Zuchri. (2014). Pengaruh Kompensasi terhadap Produktivias Kerja Karyawan pada PT Asuransi Jiwasraya Gorontalo. Jurnal Manajemen, 18 (3): 55-62.

Ardana, I. K., Mujiati, N. W., \& Major, I. M. (2012). Human Resource Management, 1th ed.Yogyakarta: Graha Science.

Arsyad, Muhammad. 2014. The Importance of Working discipline to Improve Employee's Working Productivity of Motor Vessel Manufacturing Company in Makassar Shipyard.Business Management and Strategy, 5(2): 2157-6068.

Bharata, Andhi. (2016). The Influence of Compensation and Training toward Work Discipline and its impact on The Employees' Performance in The Research Center of Science and Technology (PUSPIPTEK).Journal The WINNERS, 17 (1): 50-61.

Christian, Fitri Afriani \& Farida, Lena. (2016). Pengaruh Disiplin Kerja terhadap Produktivitas Kerja Karyawan bagian Produksi Pabrik Kelapa Sawit (PKS) PT. Perkebunan Nusantara V Sei Rokan Kec. Pagaran Tapah Darussalam Kab. Rokan Hulu. JOM FISIP, 3 (1): 30-51.

Elqadri, Mustafa Zaenal., Wardoyo, Dewi Tri Wijayati dan Priyono. (2015). The Influence of Motivation and Discipline Work against Employee Work Productivity Tona' an Markets.Review of European Studies, 7(12): 70-91.

Firmandari, Nuraini. (2014). Pengaruh Kompensasi terhadap Kinerja Karyawan dengan Motivasi Kerja sebagai Variabel Moderasi (Studi pada Bank Syariah Mandiri Kantor Cabang Yogyakarta). Jurnal Ekonomi dan Bisnis Islam. 9 (1): 1907-9109.

Gabriel C, Mgbemena, Stella I, Mbah \& Daniel C, Ejike. (2015). Impact of Effective Employee Performance Management on Organizational 
Productivity: A Study of Anambra State Civil Service System, Nigeria.The International Journal of Business and Management, 3(11): 2321-8916.

Hamali, Arif Yusuf. (2013). Pengaruh Motivasi terhadap Produktivitas Kerja: Studi Kasus pada PT X Bandung. Journal The WINNERS, 14 (2): 77-86.

Hanaysha, Jalal.(2016). Testing The Effects of Employee Empowerment, teamwork and Employee Training on Employee Productivity in Higher Education Sector.International Journal of Learning and Development, 6(1): 2164-4063.

Irbayuni, Sulastri. (2012). Pengaruh Kompensasi, Kepuasan Kerja dan Komitmen Organisasi terhadap keinginan untuk Pindah Kerja Pada PT. Surya Sumber Daya Energi Surabaya. Jurnal NeO-Bis, 6 (1): 34-52.

Jayarathna, S.M.D.Y. (2014) .An Empirical Investigation of the Impact of Employee Motivation and Productivity of Executive Employees with Special Reference to the Apparel Industry in Sri Lanka. International Journal of Science and Research, 3 (3): 2319-7064.

Khan, Dr. M. S. \& Gautam, Shalini. (2014). A Study of Impact of Motivation on Productivity of Employee.The International Journal of Business \& Management, 2 (12): 55-69.

Labudo, Yusritha. (2013). Disiplin Kerja dan Kompensasi Pengaruhnya terhadap Produktivitas Karyawan. Jurnal EMBA, 1 (3): 2303-1174.

Maduka, Chukwuma. Edwin \&Okafor, Obiefuna. (2014). Effect of Motivation on Employee Productivity: A Study of Manufacturing Companies in Nnewi.International Journal of Managerial Studies and Research,2(7): 137-147.

Mangkunegara, Anwar Prabu \& Octorend, Tinton Rumbungan.(2015). Effect of Work Discipline, Work Motivation and Job Satisfaction on Employee Organizational Commitment in The Company (Case Study in PT. Dada Indonesia).UniversalJournal of Management,3(8): 318-328.

Ponnu, C.H. \& Chuach, C.C. (2010). Organizational commitment, organizational justice and employee turnover in Malaysia.African Journal of Business Management, 4 (13): 2676-2692.

Purnama, Ridwan. (2008). Pengaruh Motivasi Kerja terhadap Produktivitas Kerja Karyawan pada Bagian Produksi CV. Epsilon Bandung.Jurnal Strategic, 7 (14): 90-112. 
Purwanto, Agus Budi \& Wulandari, Octavia. (2016). Pengaruh Motivasi, Kompensasi dan Lingkungan Kerja terhadap Produktivitas Kerja Karyawan. Bulten Bisnis \& Manajemen, 2 (1): 2442-885X.

Rahmawati, Desi. (2013). Pengaruh Motivasi terhadap Produktivitas Kerja Karyawan PT Fajar Berlian Tulungagung.Jurnal Universitas Tulungagung Bonorowo, 1 (1): 90-110.

Ruauw, Astria C.N, Lengkong, Deysi \& Mandey, Jantje.(2015). Pengaruh Disiplin Kerja terhadap Produktivitas Pegawai (Suatu Studi di Kantor Kelurahan Tingkulu Kecamatan Wanea Kota Manado). JAP, 3 (31): 98121.

Saharuddin \& Sulaiman. (2016). The Effect of Promotion and Compensation Toward Working Productivity Trough Job Satisfaction and Working Motivation of Employees in The Department of Water and Mineral Resources Energy North Aceh District.International Journal of Business and Management Invention, 5 (10): 2319-8028.

Salisu, Jamilu B, Chinyio, Ezekiel \& Suresh, Subashini. (2015). The Impact of Compensation on The Job Satisfaction of Public Sector Construction Workers of Jigawa State of Nigeria.The Business and Management Review, 6 (4): 33-49.

Saputra, Andri. (2014). Pengaruh Keselamatan Kerja Terhadap Produktivitas Kerja Karyawan Pada PT. Buran Nusa Respati Di Kecamatan Anggana Kabupaten Kukar.eJournalIlmu Pemerintahan, 2 (3): 3059-3069.

Sutanto, Eddy Madiono \& Patty, Ferdian Mario. (2014). Persepsi akan Gaji, Motivasi Kerja dan Kinerja Karyawan PT. Amita Bara Sejahtera. Journal of Business and Banking, 4 (1): 2088-7841.

Sutrisno, Sugeng. (2013). Pengaruh disiplin kerja dan motivasi kerja terhadap kinerja pegawai negeri sipil (studi di kantor dinas sosial provinsi jawa tengah).Jurnal Ilmiah dinamika ekonomi dan bisnis, 1 (1): 90-120.

Suwondo, Diah Indriani \& Sutanto, Eddy Madiono. (2015). Hubungan Lingkungan Kerja, disiplin kerja dan Kinerja Karyawan. Jurnal Manajemen dan Kewirausahaan, 17 (2): 2338-8234.

Suwuh, Meisy. (2015). Effect of Motivation on Employee Productivity: A Study of Manufacturing Companies in Nnewi.International Journal of Managerial Studies and Research,2(7): 137-147.

Syahrial, Andy, Brahmasari, Ida Aju \& Nugroho, Riyadi.(2016). Effect of Emotional Quotient, Servant Leadership, Complexity of Task, Cultural 
Ni Kadek Ira Agustini. Pengaruh Kompensasi, Disiplin Kerja...

Organization of Work Motivation and Performance of Civil State Apparatus (ASN) in WajoSouth Sulawesi Province.International Journal of Business and Management Invention, 5(6): 71-88.

Wardoyo, Dewi Tri Wijayati. (2016). The Influence of the Discipline and Compensation against Work Productivity (Study on the Security Services Company, PT Garuda Milky Artha Surabaya).International Journal of Business and Management,11(1) 112-134.

Weldeyohannes, Gebremedhin.(2015). Employee Motivation and its Impact on Productivity in the Case of National Alcohol and Liquor Factory (NALF).Journal of Property, Investment and Development, 15 (2) 2422$846 \mathrm{X}$.

Yamoah, Emmanuel Erastus. (2013). Relationship Between Compensation and Employee Productivity.Singaporean Journal of Business Economices and Management Studies, 2 (1): 1112-1125

Yuliandari, Kadek Ni, Bagia, I Wayan \& Suwendra, I Wayan. (2014). Pengaruh Kompensasi dan Lingkungan Kerja terhadap Produktivitas Kerja Karyawan Bagian Loster pada UD Yuri Desa Pangkuh Buluh Kecamatan Melaya Kabupaten Jembrana. E-Journal Bisma Universitas Pendidikan Ganesha, 2 (2): 78-90. 